\title{
A RECONNAISSANCE-SCALE GIS-BASED MULTICRITERIA DECISION ANALYSIS TO SUPPORT SUSTAINABLE BIOCHAR USE: POLAND AS A CASE STUDY
}

\author{
Agnieszka E LATAWIEC ${ }^{\mathrm{a}, \mathrm{b}, \mathrm{c}, \mathrm{d}}$, Lewis PEAKE ${ }^{\mathrm{c}}$, Helen BAXTER ${ }^{\mathrm{e}}$, Gerard CORNELISSEN ${ }^{\mathrm{f}, \mathrm{g}}$, \\ Katarzyna GROTKIEWICZ ${ }^{\text {d }}$, Sarah HALEf, Jolanta B KRÓLCZYK ${ }^{\text {h }}$, Maciej KUBON ${ }^{\text {d, }}$, \\ Artur ŁOPATKA ${ }^{\mathrm{i}}$, Agnieszka MEDYNSKA-JURASZEK, Brian J REID ${ }^{c}$, Grzegorz SIEBIELEC, \\ Saran P SOHI ${ }^{k}$, Zofia SPIAK ${ }^{1}$, Bernardo BN STRASSBURG ${ }^{\mathrm{a}, \mathrm{b}}$ \\ anternational Institute for Sustainability, Estrada Dona Castorina 124, 22460-320, Rio de Janeiro, Brazil \\ ${ }^{b}$ Rio Conservation and Sustainability Science Centre, Department of Geography and the Environment, Pontifical \\ Catholic University of Rio de Janeiro, 22453900 Rio de Janeiro, Brazil \\ 'University of East Anglia, School of Environmental Science, Norwich, NR4 7TJ, United Kingdom \\ ${ }^{d}$ Institute of Agricultural Engineering and Informatics, Faculty of Production and Power Engineering, University \\ of Agriculture in Krakow, Balicka 116B, 30-149 Krakow, Poland \\ ${ }^{e}$ National Centre for Resilience, School of Interdisciplinary Studies, The University of Glasgow, \\ Dumfries Campus, Dumfries DG1 4UQ, UK \\ ${ }^{f}$ Norwegian Geotechnical Institute (NGI), Environmental Department, Sognsveien 72, 0855 Oslo, Norway \\ ${ }^{8}$ Institute for Environmental Sciences (IMV), Norwegian University of Life Sciences (NMBU), \\ PO Box 5003, 1432 Ås, Norway \\ ${ }^{h}$ Department of Manufacturing Engineering and Production Automation, Faculty of Mechanical Engineering, \\ Opole University of Technology, Mikołajczyka 5, 45-271 Opole, Poland \\ institute of Soil Science and Plant Cultivation - State Research Institute, Czartoryskich 8 , \\ 24-100 Pulawy, Poland \\ ${ }^{j}$ Wroclaw University of Environmental and Life Sciences, C.K. Norwida 25, 50-375 Wroclaw, Poland \\ ${ }^{k} U K$ Biochar Research Centre, School of GeoSciences, University of Edinburgh, The King's Buildings, \\ West Mains Road, Edinburgh, EH9 3JN, UK \\ 'Department of Plant Nutrition, University of Environmental and Life Sciences, \\ ul. Norwida 25, 50-375 Wrocław, Poland
}

Submitted 07 Jun. 2016; accepted 02 May 2017

\begin{abstract}
Although increasing numbers of research papers regarding biochar are being published worldwide, in some countries growing interest in biochar has only recently been observed; this is true of Poland. We analysed information on biochar research in Poland alongside lessons learned elsewhere in order to identify the significant opportunities and risks associated with biochar use. This data fed into a GIS-based multicriteria analysis to identify areas where biochar application could deliver greatest benefit. We found that $21.8 \%$ of agricultural land in Poland has at least moderate indication for biochar use (soil organic matter below $2 \%$ and $\mathrm{pH}$ below 5.5 ), while $1.5 \%$ was categorized as a priority as it also exhibited contamination. Potential barriers identified included biomass availability and associated risks of indirect land-use change due to possible national and transnational biomass production displacement. Biochar use could have positive global consequences as a climate change mitigation strategy, particularly relevant in a country with limited alternatives. Scaling up a mitigation technology that is viable on account of its co-benefits might
\end{abstract}

Corresponding author: Agnieszka E Latawiec

E-mail: a.latawiec@iis-rio.org 
be cost-effective, which could, in turn, adjust national perspectives and stronger involvement in developing mitigation policies at the regional level. Biochar has much promise in temperate conditions and further research should therefore be assigned to explore biochar's environmental and socio-economic impacts.

Keywords: biochar, carbon sequestration, GIS-based multicriteria analysis, land remediation, sustainable agricultural production.

Online supplementary material: Supporting information for this paper is available as online supplementary material at https://doi.org/10.3846/16486897.2017.1326924

\section{Introduction}

Biochar is considered a tool of potential relevance to sustainable agricultural development (Sohi et al. 2010; Zimmerman et al. 2011; Jindo et al. 2012). It influences a range of soil physical, chemical and biological properties, in ways that tend to favour crop productivity (Lehmann, Josef 2009). This influence varies according to environmental factors, soil type and the type of biochar used (Biederman, Harpole 2013). Productivity increases attributed to biochar tend to have been greatest for soils with low $\mathrm{pH}$ and coarse texture (Cornelissen et al. 2013; Haefele et al. 2011; Sohi 2012; Yeboah et al. 2009). The meta-analysis of Jeffery et al. (2011) reported an overall grand mean crop yield increase of $10 \%$ with the range between -28 and $39 \%$, while others report yield impacts ranging from $-71 \%$ to $324 \%$ (Sohi et al. 2009). The largest yield increases have been reported where a combination of biochar and fertilizer has been used (Gathorne-Hardy et al. 2009; Peng et al. 2011).

The practice of applying charcoal to soil to improve soil fertility and mitigate contamination is not a new concept (Glaser et al. 2002). However, the scientific study of using biochar to improve the properties of soils is relatively new. Over recent years there has been increasing interest, mainly in developed countries, to substantiate the benefits and the mechanistic explanation for these outcomes. In parallel, field experiments have been undertaken in developing countries to investigate whether biochar is a cheap, practical and viable addition to fertilizers and organic inputs to increase soil quality and benefit yields on poor tropical soils (Cornelissen et al. 2013; Crane-Droesch et al. 2013; Yamato et al. 2006). Recent research also shows that biochar application should shift away from on-farm production and application of pure biochar, towards combined biochar-inorganic fertilizer products (Clare et al. 2014).

Considering temperate climate, an example of a European country, where limited research related to biochar has been carried out is Poland. Agriculture plays an important role in the economy of the country: it is the only sector where exports systematically exceed imports (CSO 2013). Favourable location of the country at the crossroads of main communication routes in Europe enables agricultural products from Poland to reach over half a billion of consumers. Yet, current agricultural productivity in
Poland is relatively low, due to generally poor soil quality (acid soils of low organic matter content) and extensive farming (Królczyk et al. 2014; CSO 2012). Developing new sustainable and clean technologies to improve agricultural output is therefore a priority for the country. Average yields of wheat, one of the main crops, is $50 \%$ of its potential (FAO, IIASA 2010). Agricultural production is forecast to increase in the future, yet the area of arable land in Poland is diminishing due to urbanization and transport development, among other factors (Krasowicz et al. 2011; Jonczyk, Stalenga 2010). In addition, national legislation and international conventions oblige Poland to ensure greater environmental protection and management, known as "greening measures" to protect natural landscapes. To this end, a proportion of agricultural land must be managed as "Ecological Focus Areas" (BES 2013). The country is therefore an interesting example where it is necessary to develop new technologies to seek sustainable intensification of agricultural production. In recent years there has been increasing interest in biochar research in Poland (see Supplementary Material).

In this paper we provide a multi-level model for an appraisal of the potential benefits of biochar application, firstly by overlaying the spatial distribution of relevant soil variables within a GIS, and evaluating these results as the first step in a (reconnaissance-scale) multicriteria analysis. Each of the criteria feeding into this analysis are discussed in greater detail in their regional context. Finally, non-physical, and less tangible, socioeconomic and political factors which would need to be considered in a more detailed analysis, are briefly presented.

The development of spatial decision support systems (SDSS), such as GIS, and their successful integration with multicriteria decision-making methods (MCDM) has been well summarized by Malczewski (2004). One of the primary uses of such systems has been to evaluate rural land use options, a concept which predates computerization, in the form of conventional map overlays (FAO 1976). The "suitabilities" evaluated by such systems have typically been types of land use, as opposed to land treatments, but as both the technologies and the methodologies have advanced, the scope of such spatial analyses seems almost unlimited. Though still unusual, such analyses have included individual soil treatments (Passuello et al. 2012), and even biochar (Ahmed et al. 2010). An 
important factor in any spatial analysis is scale. While detailed land use planning decisions would be appropriate at a large scale, e.g. 1:25,000, here, at the countrywide scale, only reconnaissance level considerations are realistic.

With the increasing intensification of agriculture, many temperate countries interested in using biochar now have an opportunity to benefit from lessons learned elsewhere, so as to maximize agricultural productivity and protect ecosystem services. Poland, with its twin pressures of large areas of relatively low quality agricultural land, and losses of farmland to infrastructure, alongside endemic environmental concerns, is well placed to explore the potential of such long-term land improvement without the need for expensive or harmful intensification. Furthermore large areas of land which are marginal for agriculture in Poland could nevertheless produce feedstock for biochar. Although the focus here is on the regional context, general conclusions and implications for decision-making are transferable to other countries. The most pertinent research caveats discussed here may also be particularly relevant in the regions where biochar research has not been taken up. Hence, places with little or no data for the suitability of biochar, could benefit from the results of MCDM applied to physically and socioeconomically similar areas.

\section{Methods}

A content analysis was performed (Bryman 2008) to select the most pertinent factors underlying the successful

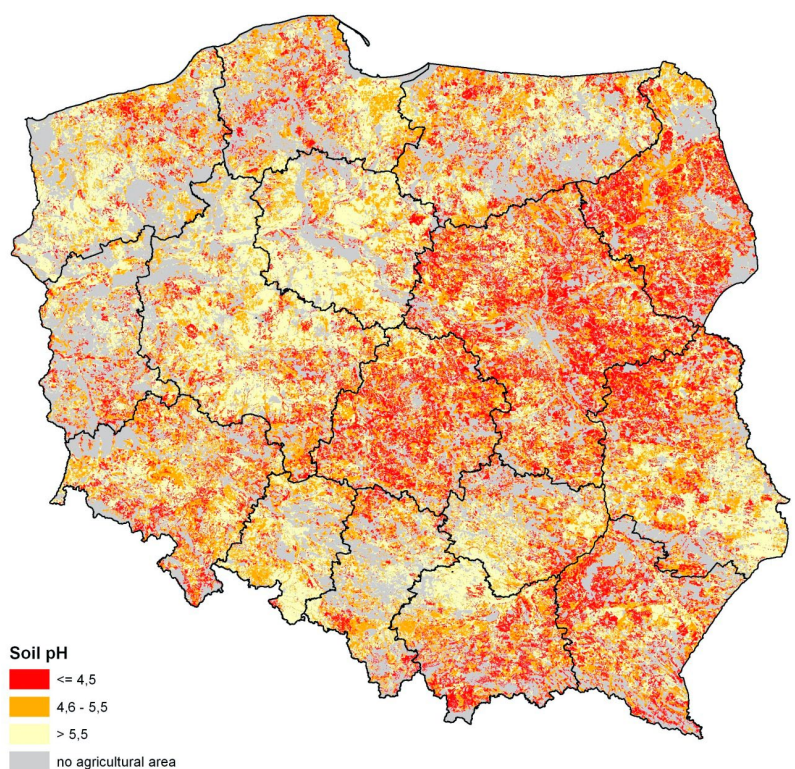

Fig. 1A. Soil acidity in Poland. The soils below pH 4.5 are very acidic and soils with $\mathrm{pH}$ range $4.5-5.5$ are acidic according to criteria used in assessment of soils in Poland. Most of the country is covered by the areas of acid soils with $\mathrm{pH}$ below 5.5. Supplementary Material includes data on each category (medium and strong potential) per region in Poland application of biochar. Drawing on a literature review and expert opinion, the most likely factors that would drive successful use of biochar in temperate regions were determined to be soil $\mathrm{pH}$, soil organic matter, soil texture and contaminant loads. These variables were overlaid spatially to produce the first map for Poland of potential areas that could benefit from biochar application in terms of increasing agricultural productivity and mitigating soil contamination.

The soil acidity data layer (Fig. 1A) was derived through a ranking method, assigning topsoil $\mathrm{pH}$ data ( $\mathrm{pH}$ in $\mathrm{KCl}$ ) (Łopatka et al. 2007) at approximately 45000 sampling locations (Terelak et al. 1997) to polygons of the digitized soil agricultural map (Stuczyński, Jadszczyszyn 2007). The soil contamination data layer (Fig. 1B) was produced through Inverse Distance Weighted (IDW) interpolation of topsoil total cadmium data representing the same 45000 sampling locations (Terelak et al. 1997) followed by averaging values to polygons of soil in an agricultural map 1:100000 (Terelak et al. 1997). Cadmium was selected for calculation of metal inactivation needs due to its potential risk to uptake in the food chain (Siebielec et al. 2008). It has also been correlated to other metals of similar origin (industry, soil parent rock material), for example, zinc and lead. According to national regulations the threshold for $\mathrm{Cd}$ content in agricultural soils is $4 \mathrm{mg} \mathrm{kg}^{-1}$, and this value was applied for mapping. Above this level the soils should be subjected to remediation. The Polish agricultural threshold value for Cd (of $4 \mathrm{mg} \mathrm{kg}^{-1}$ ) is of immediate relevance to the framing of this manuscript and is in keeping with other threshold values applicable to the EU; for example, the UK Soil Guidance Values for allotment soils $\left(1.8 \mathrm{mg} \mathrm{kg}^{-1}\right)$ and residential soils $\left(10 \mathrm{mg} \mathrm{kg}^{-1}\right)$ (Martin et al. 2009). It is noteworthy that each country has its own thresholds for heavy metal contamination and criteria to evaluate contaminated land. Validation of interpolation was performed using an independent set of samples (216 locations across the country) and revealed standard errors of 0.94 and 0.54 for $\mathrm{pH}$ and $\mathrm{Cd}$ content, respectively.

All data was imported and overlaid using ArcGIS v.9.2 software. Upon the literature review and expert consultation, the following criteria were adopted to prioritize the areas for biochar application (strong indication): soils contaminated with cadmium $\left(>4 \mathrm{mg} \mathrm{kg}^{-1}\right.$ ) or characterized by soil organic matter below $1 \%$ (very low content according to environmental legislation) and $\mathrm{pH}<=4.5$ (very acidic soil according to criteria used in assessment of soils in Poland) and being sands. Soil organic matter content and soil texture are shown in the Figure 1C and $1 \mathrm{D}$, respectively. To classify areas as those with medium potential for biochar use the following criteria were used: soil organic matter below (or equal to) $2 \%$ (considered low by environmental guidelines) with $\mathrm{pH}$ lower or equal to 5.5 (considered acid soil) and with soil texture being 


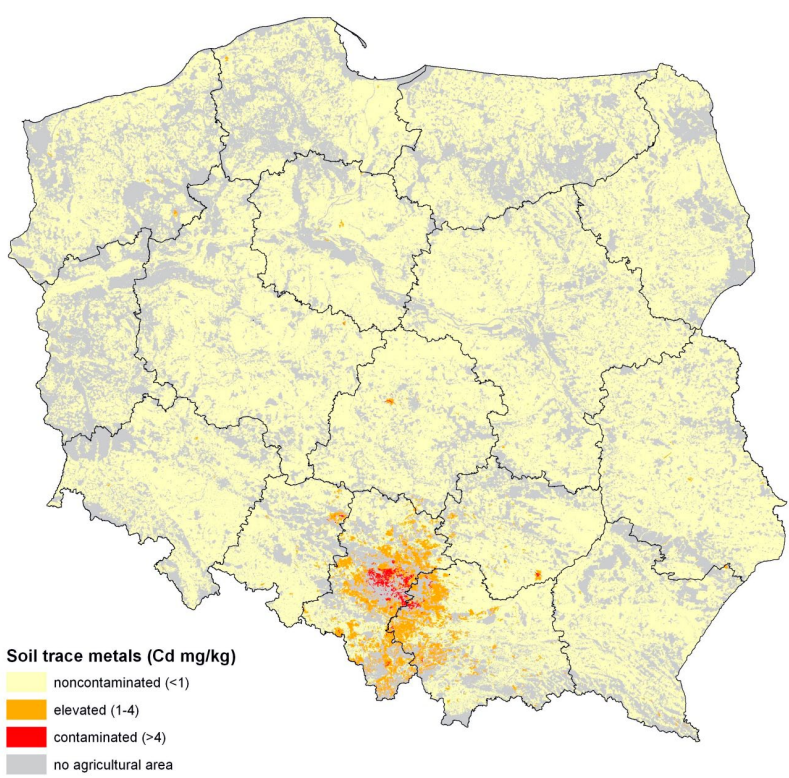

Fig. 1B. Soil contamination with trace metals (cadmium) in Poland. According to national regulations the threshold for $\mathrm{Cd}$ content in agricultural soils is $4 \mathrm{mg} \mathrm{kg}^{-1}$. Above this level the soils should be subjected to remediation

sand or loamy sand. Any area with elevated levels of contamination would also be classified as having medium potential for biochar use. The flowchart of methodology is presented in the Figure 2.

\section{Results and discussion}

\subsection{Increasing organic matter and acidity regulation}

In Poland, most of the soils are characterized by low to average contents of soil organic matter (Fig. 1C). Soils classified as very acid and acid occupy over $50 \%$ of the country (Fig. 1A; Siebielec et al. 2012) and over 70\% of the soils in the country require periodic liming to manage $\mathrm{pH}$ (Supplementary Material). On this account and given soil texture (high sand content), we found that $21.8 \%$ of the agricultural area in Poland is characterized by a medium potential for biochar use, while strong potential was found for $1.5 \%$ of the agricultural area in Poland (Fig. 3).

Soil acidity and low humus content are the biggest threats to soil quality in Poland according to the State Research Institute of Soil Science and Plant Cultivation (Siebielec et al. 2012). Furthermore, common agricultural crops in Poland, such as wheat and barley, require $\mathrm{pH}$ over 6.5 to give highest yields and lower $\mathrm{pH}$ results in lower yields (by $15-20 \%$ of the possible attainable yield) (Fotyma et al. 2009; Carver, Ownby 1995). Increasing pH of soils is therefore a priority and necessity within agricultural management in Poland. Furthermore, across Europe soil is under increasing pressure from inappropriate agricultural and industry practices, which undermine the capacity of soil to continue to perform its crucial ecosystem

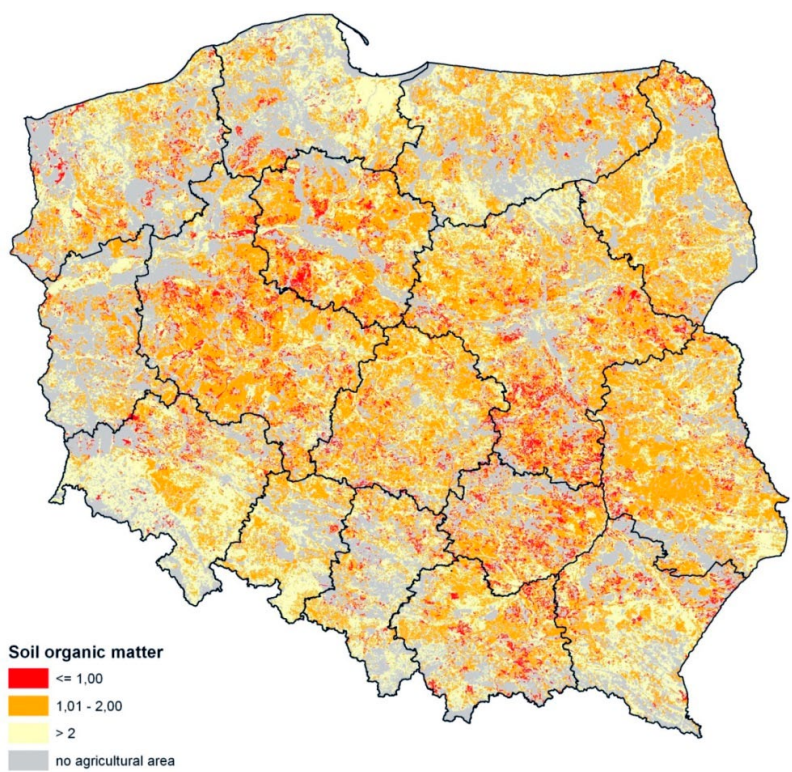

Fig. 1C. Soil organic matter in Poland ( Stuczyński, Jadczyszyn 2007; discussion in the Supplementary Material)

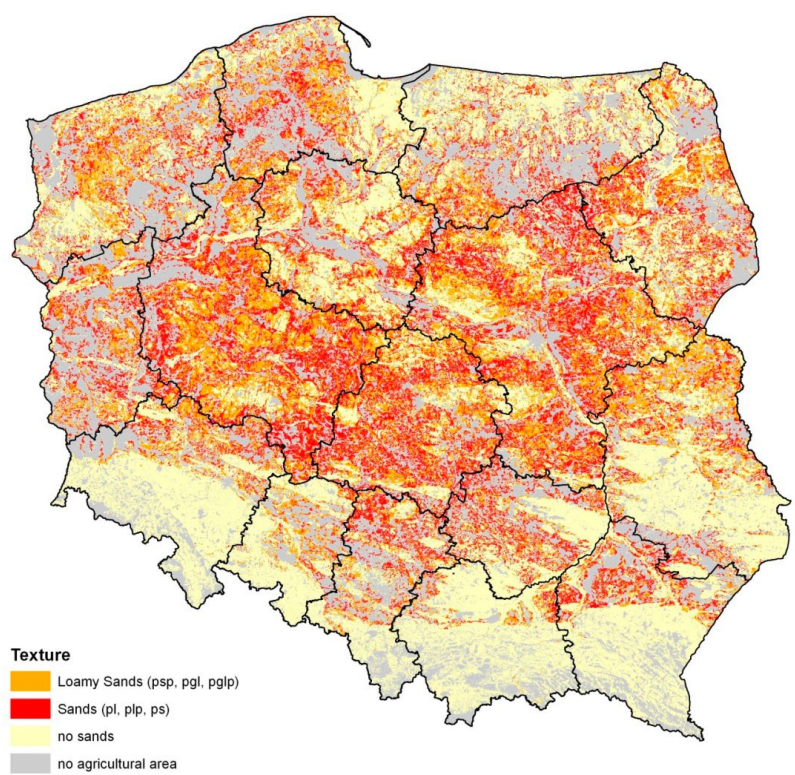

Fig. 1D. Soil texture in Poland

services (COM 2006a). Sixteen percent of Europe's total land area is affected by erosion ( $12 \%$ and $4 \%$ subject to water and wind erosion, respectively) while $45 \%$ of European soils have low organic matter content (COM 2006b).

In this context biochar is a potential tool to increase soil $\mathrm{pH}$ and soil organic matter content. The $\mathrm{pH}$ of biochar can vary from pH 4 to 12 (Lehmann 2007), but in general, when biochar is produced at a sufficient temperature (over $350^{\circ} \mathrm{C}$ ) for adequate time (which, depending on the oven and the pyrolysis type, can be up to a few hours) to ensure that biochar has little ash and a reasonable carbon content 


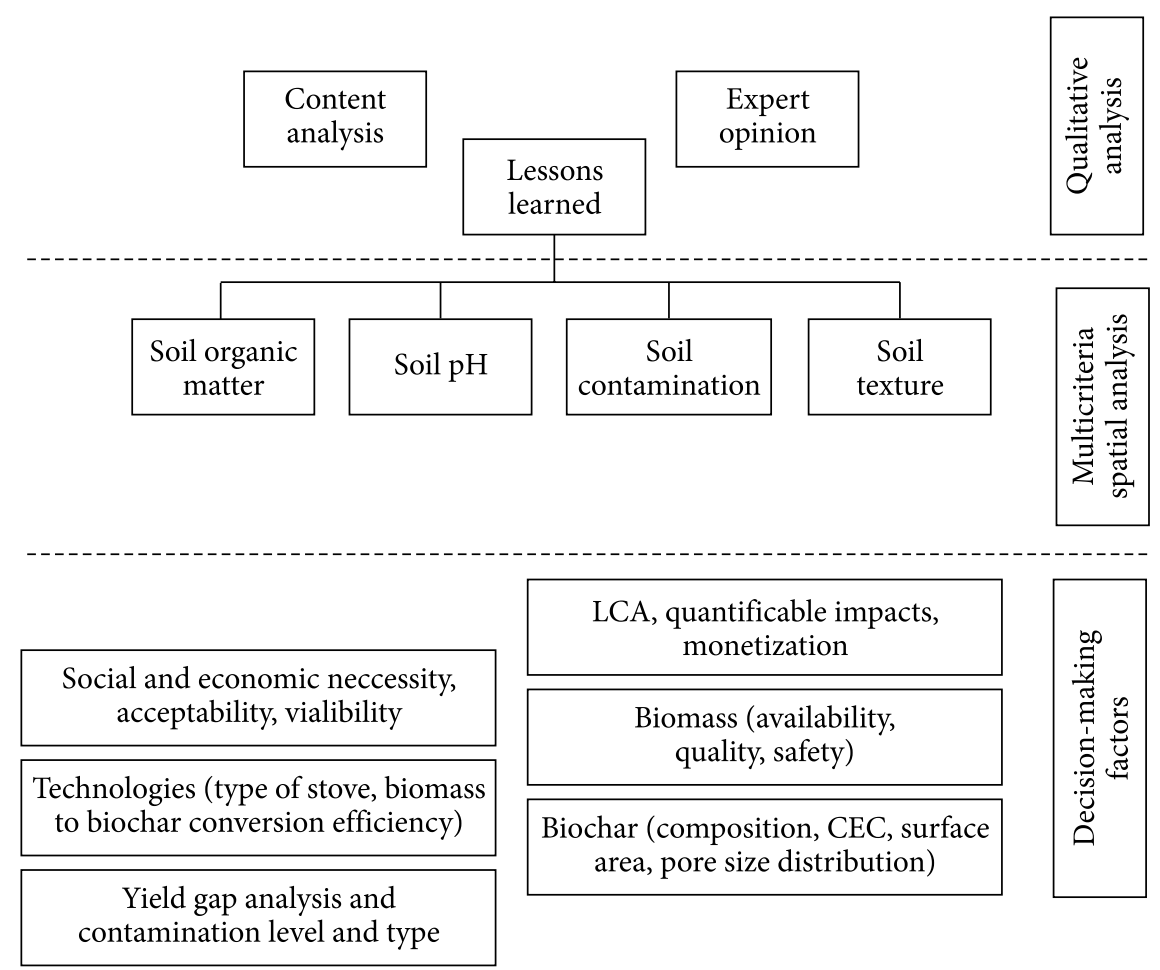

Fig. 2. Flowchart of the 3-step methodology to derive prioritization of biochar use for sustainable land management. First, the literature was reviewed to provide data input to spatial prioritization. In this study we used organic matter content, soil $\mathrm{pH}$, soil texture and contamination level to arrive at the prioritization map. Subsequently we discuss other benefits of biochar and the most important practical considerations that must be taken into account before biochar is applied. Some considerations from the step 3 of this methodology could enrich spatial prioritization; their use however is subject to data availability (and therefore not included in this study)

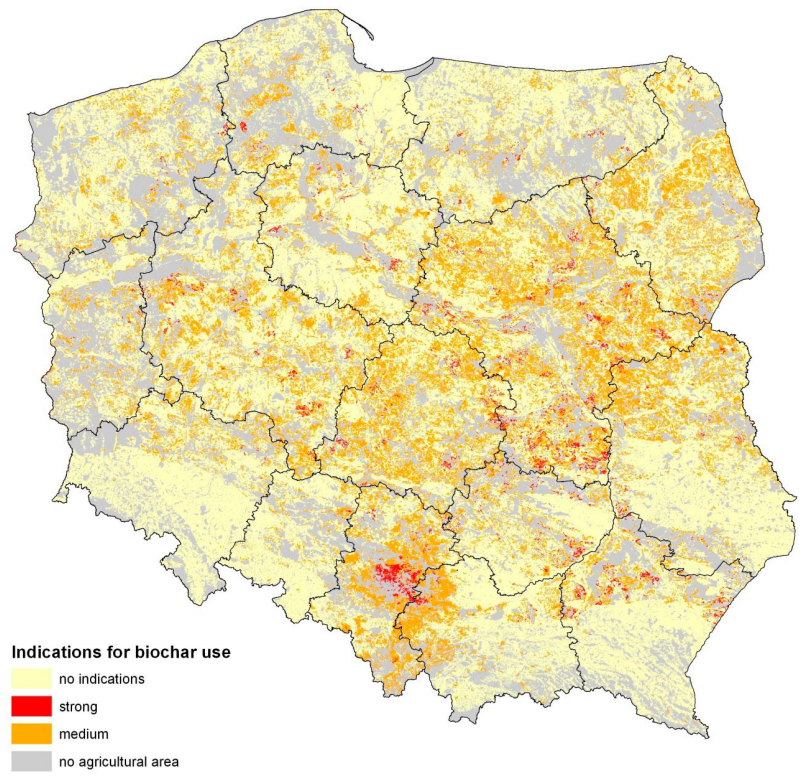

Fig. 3. Preliminary prioritization of areas that could benefit from biochar use. In orange are the areas with medium potential for biochar use: elevated cadmium OR (SOM $<=$ 2 AND $\mathrm{pH}<=5.5$ AND (texture = sand OR loamy sand)), which equals $21.8 \%$ of the agricultural area. Red colour indicates strong potential for biochar application: soils contaminated with cadmium OR (SOM $<=1$ AND $\mathrm{pH}<=4.5$ AND texture $=$ sand), which equals to $1.5 \%$ of the agricultural area in Poland (normally around or above 50\%), it displays an alkaline $\mathrm{pH}$ (above 7). A number of studies on different types of biochar from different pyrolysis processes demonstrated a liming effect of biochar in the soil (Gaskin et al. 2010; Kloss et al. 2012, 2014; Singh et al. 2010; Uzoma et al. 2011). When biochar is added to an acidic soil, it tends to increase soil $\mathrm{pH}$ with a broadly beneficial effect, particularly with respect to nutrient cycling, e.g. biochar additions of $2 \% \mathrm{w} / \mathrm{w}$ have been found to raise $\mathrm{pH}$ by 1.0 (Laird et al. 2010). It has been claimed that adding inappropriately alkaline types of biochar can exacerbate an unfavourably high soil pH (Kishimoto, Sugiura 1985), however such soils tend to be highly buffered and in practice the effect is often neutral (Schmidt et al. 2014). Diminished soil acidity accompanied with yield improvement has been reported by many authors (Major et al. 2010; Van Zwieten et al. 2010; Vaccari et al. 2011). The effect of biochar on soil and yields is not only dependent on biochar but also on the soil characteristics such as soil texture, soil organic matter and $\mathrm{pH}$. Most of the pot and field experiments were related to highly weathered, nutrient-poor tropical soils (Glaser et al. 2002; Blackwell et al. 2009; Sohi et al. 2010). According to Verheijen et al. (2010) the highest increase in soil $\mathrm{pH}$ is observed as a consequence of biochar addition when the initial $\mathrm{pH}$ of soil is low and positive effects on crop productivity might be a result of liming effect and 
nutrients cycling (Jeffery et al. 2011; Powlson et al. 2011; Rajkovich et al. 2012; Verheijen et al. 2010). In a recent review of 57 field experiments across all continents (Tammeorg 2014) observed the highest increase in crop productivity following biochar addition in sandy soils with a low soil matter organic content. Biochar also increased soil organic matter content and supported the retention of nutrients and water (Tammeorg 2014). Positive effects on soil and plants were found by Kuka et al. (2013) and Yang et al. (2013), which might partly be a result of the increase in $\mathrm{pH}$. Sandy soils are likely to have greatest benefits from biochar than clayey soils (Atkinson et al. 2010), which is promising in the context of Polish soils.

\subsection{Biochar and contaminated land remediation}

Many years of intensive land use due to coal mining and metal ore smelting activities have resulted in serious contamination of some arable soils, especially in Upper Silesia (southern Poland) (Loska et al. 2004; Karczewska, Kabała 2010), therefore we found this area to have a strong potential to benefit from biochar use (Fig. 3). The degree of the contamination problem is not entirely known, but elevated concentrations of heavy metals, PAHs, oil derivatives have been reported in arable soils throughout Poland (Fig. 1B; Tóth et al. 2016a, 2016b; Siebielec et al. 2012). The in situ application of amendments to contaminated soils to bind pollutants (to provide conditions that promote plant growth and stimulate ecological restoration) have been reported worldwide, but in Poland such practices are rare.

Biochar is highly porous and has functional groups that enable it to interact with both organic and inorganic species present in soil (Amonette, Joseph 2009; Reid et al. 2013). Thus, there is potential to remediate contaminated soils through the sorption and entrapment of contaminants by biochar. Although the use of activated carbon to treat contaminated soils and sediments is well established (Hale et al. 2012; Werner et al. 2005; Zimmerman et al. 2004), the application of biochar as a partially activated material to treat contaminated soil is less investigated. Regarding inorganic contaminants, several studies have shown the potential for a range of biochar materials to ameliorate soil contaminated with metals and metalloids, these include: broiler litter derived biochar $(\mathrm{Cu}, \mathrm{Ni}$ and Cd) (Uchimiya et al. 2010); hardwood-derived biochar (Cd and Zn) (Beesley et al. 2010); pecan-shell biochar (Zn) (Novak et al. 2009); biochar from orchard prunings (Cd, $\mathrm{Pb}$ and $\mathrm{Zn}$ ) (Fellet et al. 2011); rice straw and bean straw biochar (Cd) (Zheng et al. 2015), and; sewage sludge bichar (As) (Khan et al. 2014).

Research carried out in Poland to date has principally focused on biochar binding of organic pollutants (Oleszczuk et al. 2014, 2012a, 2012b; Jośko et al. 2013) as well as for composting (Czekała et al. 2016; Malińska et al. 2014, 2016, 2017). Other pilot studies of biochar use have been made in south-west Poland in the remediation of soils contaminated with multiple trace metals $(\mathrm{Cu}, \mathrm{Pb}, \mathrm{Zn}, \mathrm{Cd}$, As, Ni) from copper smelters. These suggest that biochar made from wheat straw and miscanthus and used at $2 \%$ $(w / w)$ concentration could reduce bioavailability of $\mathrm{Cu}$, $\mathrm{Zn}$ and $\mathrm{Pb}$ and uptake by plants growing on highly contaminated soils (Medyńska-Juraszek 2014). We note, however, that biochar-metal associations, while they mitigate risks, do not necessarily reduce risks to below acceptable levels. Here it is important to acknowledge: i) the extent to which metal concentrations are elevated (in cases of gross contamination biochar may lack sufficient adsorptive capacity to fully mitigate metal risks) and ii) prevailing environmental conditions, such as $\mathrm{pH}$ and redox potential (as prevailing conditions may be unconducive to metal sorption; favouring metal dissolution to the soil pore water) (Zheng et al. 2015; Zhang et al. 2016). Nonetheless, given these initial bioremediation-focused studies that suggest that biochar amendment to soil is a useful tool in reducing environmental risk of pollutants, we emphasize the need for further investigation.

In addition to heavy metals, elevated concentrations of pesticides have been reported in Poland (Sutrawska, Kołodziejczyk 2006; Eurostat 2016). At such locations biochar, on account of its sorptive capacity, could ameliorate the impact of pesticides by reducing exposure of non-target receptors, for example, soil biota, groundwater, surface waters and aquatic organisms. Reduced pesticide availability in soils would also be anticipated to reduce pesticide uptake to food crops and further accumulation into the food chain. Such reduced soil-to-plant transfer of pesticides has been reported in biochar-amended soils for both insecticides (Pylypiw et al. 1997) and herbicides (Pylypiw et al. 1993). Direct biochar placement within soils or as a permeable barrier (e.g. trenching) in the riparian zone could provide mitigation of herbicide transfer to surface waters. Biochar may provide an important sink where excess runoff occurs but the knowledge on this topic is still scarce. Although in Poland little is known about pesticides residues in general, some areas of the country (such as Lower Silesia and Opole Silesia) were reported to have high residues of herbicides and fungicides in soils, water, plants and animal tissues, which corresponds to the high doses of pesticides used in these regions (Sutrawska, Kołodziejczyk 2006). Research into this area would be of particular use in order to prioritize biochar interventions in areas of greatest concern (Weissteiner et al. 2014; Biziuk 2009; Sutrawska, Kołodziejczyk 2006).

It is worth noting that the map of potential for biochar application presented here serves as visualization for a reconnaissance study. Even though our database of 45000 sampling locations is the most detailed existing soil 
survey in Poland, uncertainty in individual locations may be considerable, since spatial variability of $\mathrm{pH}$ and metal content is high, as a result of soil management by farmers, parent rock and diversity of industrial sources of contaminants in post -industrial regions. Decision making on individual locations should therefore be complemented by the analysis of soil samples collected from the location of interest.

\subsection{Physical effects in soil following biochar amendment}

Like soil organic matter, biochar can counteract both aridity in sandy soils (Uzoma et al. 2011) and improve water drainage under inundated conditions of waterlogged clay soils (Asai et al. 2009). Biochar can enhance water holding capacity (WHC) and water use efficiency, which can help to reduce water demand (Peake et al. 2014). Biocharamended soils have shown increases in WHC from 11 to $481 \%$ especially in sandier soils (Karhu et al. 2011; Southavong, Preston 2011; Uzoma et al. 2011). Sandy soils were therefore selected as priority areas in our spatial modelling.

Other physical effects of biochar include reduced bulk density (Laird et al. 2010), reduced tensile strength (Chan et al. 2007), and decreased soil strength (Busscher et al. 2010). The capacity of biochar to improve soil structure and cohesion has the potential to prevent erosion and counteract compaction, and is also directly aligned with European soil protection priorities (COM 2006a, 2006b). Since improving soil structure and WHC may lead to soil stabilization, results of such analysis would also have implications for flood-risk areas. More research is however required to assess the best candidate soils and to match this assessment with flood risks.

Poland is one of the countries in Europe with the least available water per capita (CSO 2013; Siebielec et al. 2012). The capacity of storage reservoirs in Poland is very limited ( $6 \%$ of the annual outflow of water), which does not provide adequate protection against periodic surpluses or deficits of water (Siebielec et al. 2012). Therefore using biochar to address low WHC in Poland agronomically is extremely relevant. Projected increases in evapotransporation under climate change further reinforce the potential mitigation strategies that biochar may offer to abate future water deficits (SOER 2010). As some authors showed (Devereux et al. 2012), it may be possible to reduce irrigation frequency or volume in coarse textured soils, soils with a large number of macropores or when large amounts of biochar are applied.

Another potential benefit from biochar use, unmapped here due to data scarcity, relates to nutrients. In terms of plant nutrition, biochar can have two effects: temporary fertilizing effects, on account of its ash content, and longer-term effects, such as changes to $\mathrm{pH}$ or cation exchange capacity (CEC). Discussion on potential benefits from biochar in the context of nutrient availability in Polish soil can be found in Supplementary Material.

\subsection{Potential barriers to biochar utilization}

Several important aspects relating to biochar application to soil need full consideration if biochar is to have a role to play in sustainable land management in Poland. Most pertinent are: 1) safety, 2) social acceptance, 3) lifecycle appraisal and, 4) availability of feedstock for biochar production.

\subsubsection{Biochar safety}

The over-riding prerequisite for any soil amendment is its safety. Biochar has the potential to introduce toxic chemicals into soil that could damage soil functions. Three groups of potentially toxic substances, namely: metals and metalloids (such as, $\mathrm{As}, \mathrm{Cu}, \mathrm{Pb}, \mathrm{Ni}, \mathrm{Zn}$ etc.); polycyclic aromatic hydrocarbons (PAHs); and dioxins, are the most likely agents to be present in biochar and to represent a toxicity hazard. Although environmental impacts attributable to metals, metalloids, PAHs and dioxins associated with biochar are likely to be minimal (Freddo et al. 2012; Hale et al. 2012), special care is required to ensure the feedstock materials, particularly if wastes, are not overly burdened with high concentrations of metals, metalloids, or chlorinated compounds (that may serve as dioxin precursors). In this regard virgin wood and crop waste residues are not tainted chlorinated compounds (e.g. associated with wood preservation) and these feedstocks have relatively low metal and metalloid loadings (Zheng et al. 2015) when compared to, for example, sewage sludge (Lu et al. 2016). In keeping with biochar guidance applicable to the EU, for example the Biochar Quality Mandate (Shackley et al. 2014) we advocate that biochar produced for application to agricultural land should be derived from virgin non-waste biomass feedstocks. Pyrolysis conditions should also be considered with caution, as lower pyrolysis temperatures $\left(<400{ }^{\circ} \mathrm{C}\right)$ have been reported to give biochar products with greater PAH loadings when compared with biochars produced at higher pyrolysis temperatures (Freddo et al. 2012; Hale et al. 2012).

\subsubsection{Social acceptance and inclusion into farmers' practice}

Social aspects are often omitted in the assessment of emerging technologies but are paramount for long-term utility and effectiveness of an approach (Michałek, Kuboń 2009). Indeed, in order for regional scale advantages of biochar to be achieved, diverse stakeholders, populations and decision-makers, along with scientists, have to be actively interested in optimizing biochar technology in the context of their local environment. 
Some specific research questions for biochar include: what is the social acceptance and consequence of implementing biochar into agricultural practice (e.g. job creation in sustainable agriculture)?; how would biochar work operationally and would it work for both large and small scale farmers?; would it work in small-holder closed systems (biomass production and use at the same farm)?; is there potential for biochar to be used in horticulture and organic farming?; and, finally, is it economically viable as compared with other alternatives such as the use of lime? These questions also include practical and logistical aspects of storage, transport, and farmers' incorporation of biochar into soil.

Another important aspect is to what extent the farmers would prefer to use their biomass for biochar production instead of receiving, sometimes substantial financial benefits from selling their biomass to power plants, which on the other hand, receive subsidies from the generation of "green energy". Conversely, this trend may finish, when the subsidies cease, while conversion of biomass to biochar may bring the farmers a range of more permanent benefits, such as improving the quality of soils, increasing agricultural productivity, carbon sequestration and potential payments from avoided emissions. Preliminary results show potential interest of the farmers in Poland to adopt biochar, and new studies on social acceptance of biochar application are currently being undertaken (Latawiec et al. 2017).

\subsubsection{Feedstock biomass}

Having identified candidate areas for biochar deployment based on soil conditions, two questions arise. Firstly, the feedstock that could be used to make biochar and secondly, the availability of these feedstocks, given competing current or future uses. It is widely reported that biochar deployment is biomass-intensive and may exacerbate the global challenge of meeting biomass demands from existing agricultural land (Strassburg et al. 2014). Increasing demand for biomass could lead to inadvertent adverse effects such as rebound - the economic effect of efficient use of inputs leading to increased use. This could lead to incountry pressure for biomass resources or trans-boundary effects from displacement (Strassburg et al. 2014). Decreased net emissions in Poland could result in leakage, i.e. net emissions elsewhere through indirect land-use change driven by demand for biomass. Production of biochar can also be costly and it will be essential to integrate biochar production with the recovery of energy.

The main source of biomass in Poland is wood and wheat straw (Gradziuk et al. 2001). Biomass crops such as shrub willow (Salix spp.) or elephant grass (Miscanthus giganteus) cultivation is minor, although cultivation of bioenergy crops has increased (see Supplementary Material).
Use of green waste and sewage sludge is increasing rapidly. These might emerge as important lower-cost, point-source feedstock for production of biochar. Clearly, potential conflicts exist between the use of land for food production versus its use for energy crops, and the allocation of land with the express purpose of providing feedstock for biochar production could further add to the demands put on a limited resource (if the biochar production expands beyond the use of organic waste material). Thus it remains to be investigated whether current biomass production would be enough to meet possible demands for biochar in the future and whether it would be practically feasible to increase such production. However, $30.8 \%$ of Poland is under forest, largely on land unsuitable for agriculture and which might therefore provide readily available and potentially unwanted feedstock (such as coppice trimmings or sawmill waste) with no change of use or competition for the same resource.

\subsection{Lifecycle appraisal}

Life cycle assessment (LCA) is fundamental to any implementation of biochar and encompasses broader implications and impacts. This is important in the assessment of biochar use, due to the variety of feedstock used for its production and the diversity of technologies for its conversion (Cowie et al. 2012; Lehmann, Joseph 2009). The conversion process involves toxic gases (such as CO) as well as volatiles (that can emanate as smoke) and greenhouse gases (notably $\mathrm{CH}_{4}$ ). These emissions could offset the avoided $\mathrm{CO}_{2}$ emissions associated with carbon stabilization. Emissions from modern pyrolysis units and medium-sized retort kilns should be much lower than those from traditional simple kilns, though data are often commercially confidential in this area (Meyer et al. 2011; Adam 2009).

By comparing different feedstock materials and production technologies through the use of LCA the overall positive and negative outcomes of scenarios can be compared. It is vital to match the appropriate technology with the specific situation, using research and the experiences of previous projects which can be applied to biochar production on individual farms. For example, incorporating electricity generation (De Miranda et al. 2013), and studies into carbon sequestration potential of biochar would be a good starting point (Hammond et al. 2011; Roberts et al. 2010).

Conflicting reports about the stability of the biochar matrix also exist (Gurwick et al. 2013). Although biochar carbon is more stable than carbon in any other organic form (Lehmann et al. 2009) and there is evidence that it may also stabilize incumbent soil organic matter (Bach et al. 2016; Glaser et al. 2002; Lanza et al. 2016; Smith 2016), how long exactly biochar remains stable in the 
soil and the duration of its influence on soil physical and chemical properties is not entirely certain (Sohi 2012). Establishing the recalcitrance of biochar benefits is a clear priority if a comprehensive assessment of biochar lifecycle is to be achieved.

Determining how specific local conditions and requirements change the balance of impacts for biochar production and use is important as it will illustrate the ways in which technology and production methods cannot simply be transferred between different regions with the expectations that the same benefits will be derived (Sparrevik et al. 2011; Turtoni et al. 2011). A relatively new development in LCA is life cycle sustainability assessment (LCSA) which combines traditional LCA with life cycle integrated assessment (LCIA), which incorporates social and economic analysis in order to capture a more nuanced and holistic evaluation of the impacts. Poland is well placed to instigate a comprehensive research programme which would facilitate research into quantifying and testing contrasting impact categories to contribute to the development and robustness of this methodology. This approach is particularly relevant for Poland which is in a period of rapid change as EU regulations and policy influence its development. Using LCSA to quantify the multiple considerations when selecting feedstock will enable better judgements about feedstock type and availability. This would provide a unique opportunity to track changes, learn lessons and develop an understanding of the way in which actions on the ground impact the wider sustainability of a system. As an integral part of the assessment of biochar potential in Poland, LCA must be a part of any comprehensive research effort to maximize the potential benefits from biochar production and use.

\section{Conclusions}

Given lessons learned elsewhere, a large proportion of soils in Poland could potentially benefit from biochar application. Given the abundance of acid soils with low organic matter, high metal loadings, and low agricultural yields, biochar emerges as a potentially attractive option for soil enhancement. Deployed widely and strategically, it could contribute to increased national output of agricultural commodities, land remediation and co-benefits of climate change mitigation. There are, however, challenges to be addressed, such as biomass supply. We encourage collaboration on this topic, not only because the conclusions are important for the development of sustainable agriculture, but also for economies of countries elsewhere seeking increased agricultural productivity. Poland, like many other countries characterized by extensive agriculture, will need to increase agricultural production without expanding to areas spared for nature, so the question becomes how to increase agricultural productivity without adverse environmental effects. Biochar can not only potentially contribute towards these goals, and hence the overarching priorities of sustainable land management, but can also result in food production increase while mitigating pollution and climate change, thus helping to address these pressing global challenges.

\section{Acknowledgements}

The establishment of the UK Biochar Research Centre in 2009 was underpinned by a Science and Innovation Award from the Engineering and Physical Sciences Research Council (EP/F034520/1). Katarzyna Korys is gratefully acknowledged for her help on the manuscript while working as a project assistant at the International Institute for Sustainability.

\section{References}

Ahmed, S.; Ibarrola, R.; Hammond, J.; Shackley, S.; Sohi, S.; Haszeldine, S. 2010. The potential of biochar deployment in Scotland: a preliminary assessment. Working Paper 7, UK Biochar Research Centre.

Amonette, J. E.; Joseph, S. 2009. Characteristic of biochar: mirco-chemical properties, Chapter 3 in J. Lehmann, S. Joseph (Eds.). Biochar for environmental management, science and technology. London: Earthscan.

Adam, J. C. 2009. Improved and more environmentally friendly charcoal production system using a low-cost retort-kiln (Eco-charcoal), Renewable Energy 34: 1923-1925. https://doi.org/10.1016/j.renene.2008.12.009

Asai, H.; Samson, B. K.; Stephan, H. M.; Songyikhangsuthor, K.; Homma, K.; Kiyono, Y.; Inoue, Y.; Shiraiwa T.; Horie, T. 2009. Biochar amendment techniques for upland rice production in Northern Laos. 1. Soil physical properties, leaf SPAD and grain yield, Field Crops Research 111: 81-84. https://doi.org/10.1016/j.fcr.2008.10.008

Atkinson, C. J.; Fitzgerald, J. D.; Hipps, N. A. 2010. Potential mechanisms for achieving agricultural benefits from biochar application to temperate soils: a review, Plant and Soil 337(1-2): 1-18. https://doi.org/10.1007/s11104-010-0464-5

Bach, M.; Wilske, B.; Breuer, L. 2016. Current economic obstacles to biochar use in agriculture and climate change mitigation, Carbon Management 7(3-4): 183-190. https://doi.org/10.1080/17583004.2016.1213608

Beesley, L.; Moreno-Jiménez, E.; Gomez-Eyles, J. L. 2010. Effects of biochar and greenwaste compost amendments on mobility, bioavailability and toxicity of inorganic and organic contaminants in a multi-element polluted soil, Environmental Pollution 158: 2282-2287. https://doi.org/10.1016/j.envpol.2010.02.003

BES. 2013. Greening the Common Agricultural Policy: MEPs vote on environmental measures [online]. The British Ecological Society [cited 21 March 2013]. Avaliable from Internet: http://www.britishecologicalsociety.org/blog/2013/03/21/ greening-the-cap/\#sthash.TPDrkO4t.dpufhttp://www.britishecologicalsociety.org/blog/2013/03/21/greening-the-cap/

Biederman, L. A.; Harpole, W. S. 2013. Biochar and its effects on plant productivity and nutrient cycling: a meta-analysis, Bioenergy 5(2): 202-214. https://doi.org/10.1111/gcbb.12037 
Biziuk, M. 2009. Pesticides - occurrence, marking, disposal. Warszawa: WNT (in Polish).

Blackwell, P.; Riethmuller, G.; Collins, M. 2009. Biochar application to soil, Biochar for Environmental Management: Science and Technology 1: 207-226.

Bryman, A. 2008. Social science research methods. Oxford: Oxford University Press.

Busscher, W. J.; Novak, J. M.; Evans, D. E.; Watts, D. W.; Niandou, M. A. S.; Ahmedna, M. 2010. Influence of pecan biochar on physical properties of a Norfolk loamy sand, Soil Science 175: 10-14. https://doi.org/10.1097/SS.0b013e3181cb7f46

Carver, B. F.; Ownby, J. D. 1995. Acid soil tolerance in wheat, Advances in Agronomy 54: 117-173.

https://doi.org/10.1016/S0065-2113(08)60899-8

Central Statistical Office (CSO). 2012. Concise statistical yearbook of Poland. Statistical Publishing Establishment, Warsaw (in Polish).

Central Statistical Office (CSO). 2013. Concise statistical yearbook of Poland. Statistical Publishing Establishment, Warsaw (in Polish).

Chan, K. Y.; Van Zwieten, L.; Meszaros, I.; Downie, A.; Joseph, S. 2007. Agronomic values of greenwaste biochar as a soil amendment, Soil Research 45: 629-634.

https://doi.org/10.1071/SR07109

Clare, A.; Barnes, A.; McDonagh, J.; Shackley, S. 2014. From rhetoric to reality: farmer perspectives on the economic potential of biochar in China, International Journal of Agricultural Sustainability 12(4): 440-458.

https://doi.org/10.1080/14735903.2014.927711

COM. 2006a. Commission of the European Communities. Directive of the European Parliament and of the Council establishing a framework for the protection of soil and amending Directive 2004/35/EC. Brussels, 22.9.2006. COM (2006) $232 \mathrm{final}$ 2006/0086 (COD).

COM. 2006b. Communication from the Commission to the Council, the European Parliament, the European Economic and Social Committee and the Committee of the Regions. Thematic Strategy for Soil Protection. Brussels, 22.9.2006. COM (2006) 231 final.

Cornelissen, G.; Martinsen, V.; Shitumbanuma, V.; Alling, V.; Breedveld, G. D.; Rutherford, D.; Sparrevik, M.; Hale S. E.; Obia, A.; Mulder, J. 2013. Biochar effect on maize yield and soil characteristics in five conservation farming sites in Zambia, Agronomy Journal 3: 256-274.

https://doi.org/10.3390/agronomy3020256

Cowie, A. L.; Downie, A. E.; George, B. H.; Singh, B. P.; Van Zwieten, L.; O'connell, D. 2012. Is sustainability certification for biochar the answer to environmental risks?, Pesquisa Agropecuaria Brasileira 47. https://doi.org/10.1590/s0100-204x2012000500002

Crane-Droesch, A.; Abiven, S.; Jeffery, S.; Torn, M. S. 2013. Heterogeneous global crop yield response to biochar: a meta-regression analysis, Environmental Research Letters 8: 044049. https://doi.org/10.1088/1748-9326/8/4/044049

Czekała, W.; Malińska, K.; Cáceres, R.; Janczak, D.; Dach, J.; Lewicki, A. 2016. Co-composting of poultry manure mixtures amended with biochar - The effect of biochar on temperature and C-CO 2 emission, Bioresource Technology 200: 921-927. https://doi.org/10.1016/j.biortech.2015.11.019
De Miranda, R. C.; Bailis, R.; Vilela, A. D. O. 2013. Cogenerating electricity from charcoaling: a promising new advanced technology, Energy for Sustainable Development 17: 171-176.

Devereux, R. C.; Sturrock, C. J.; Mooney, S. J. 2012. The effects of biochar on soil physical properties and winter wheat growth, Earth and Environmental Science Transactions of the Royal Society of Edinburgh 103(01): 13-18. https://doi.org/10.1017/S1755691012000011

Eurostat. 2016. Agri-environmental indicator - consumption of pesticides [online], [cited May 2017]. Available from Interenet: http://ec.europa.eu/eurostat/statistics-explained/ index.php/Agri-environmental_indicator_-_consumption_ of_pesticides

FAO. 1976. A framework for land evaluation. Soils Bulletin 32. Rome: FAO.

Fellet, G.; Marchiol, L.; Delle Vedove, G.; Peressotti, A. 2011. Application of biochar on mine tailings: effects and perspectives for land reclamation, Chemosphere 83: 1262-297.

https://doi.org/10.1016/j.chemosphere.2011.03.053

FAO; IIASA. 2010. FAO/IIASA Global Agro-ecological Assessment study (GAEZ). Food and Agriculture Organization, of the United Nations (FAO), International Institute, for Applied Systems Analysis (IIASA).

Fotyma, M.; Igras, J.; Kopiński, J. 2009. Production and environmental determinants of fertilizer management in Poland, IUNG-PIB Puławy 11: 178-2069 (in Polish).

Freddo, A.; Cai, C.; Reid, B. J. 2012. Environmental contextualisation of potential toxic elements and polycyclic aromatic hydrocarbons in biochar, Environmental Pollution 171: 1824. https://doi.org/10.1016/j.envpol.2012.07.009

Gathorne-Hardy, A.; Knight, J.; Woods, J. 2009. Biochar as a soil amendment positively interacts with nitrogen fertiliser to improve barley yields in the UK, in IOP Conference Series: Earth and Environmental Science 6: 372052.

Gaskin, J. W.; Speir, R. A.; Harris, K.; Das, K. C.; Lee, R. D.; Morris, L. A.; Fisher, D. S. 2010. Effect of peanut hull and pine chip biochar on soil nutrients, corn nutrient status, and yield, Agronomy Journal 102(2): 623-633. https://doi.org/10.2134/agronj2009.0083

Glaser, B.; Lehmann, J.; Zech, W. 2002. Ameliorating physical and chemical properties of highly weathered soils in the tropics with charcoal - a review, Biology and Fertility of Soils 35: 219-230. https://doi.org/10.1007/s00374-002-0466-4

Gradziuk, P.; Grzybek, A.; Kowalczyk, K. 2001. Straw - the biofuel. Warszawa: The village of tomorrow (in Polish).

Gurwick, N. P.; Moore, L. A.; Kelly, C.; Elias P. 2013. A systematic review of biochar research, with a focus on its stability in situ and its promise as a climate mitigation strategy, PLOS ONE 8: e75932. https://doi.org/10.1371/journal.pone.0075932

Haefele, S. M.; Konboon, Y.; Wongboon, W.; Amarante, S.; Maarifat, A. A.; Pfeiffer, E. M.; Knoblauch, C. 2011. Effects and fate of biochar from rice residues in rice-based systems, Field Crops Research 121: 430-440. https://doi.org/10.1016/j.fcr.2011.01.014

Hale, S. E.; Elmquist, M.; Brändli, R.; Hartnik, T.; Jakob, L.; Henriksen, T.; Werner, D.; Cornelissen, G. 2012. Activated carbon amendment to sequester PAHs in contaminated soil: a lysimeter field trial, Chemosphere 87(2): 177-184. https://doi.org/10.1016/j.chemosphere.2011.12.015 
Hammond, J.; Shackley, S.; Sohi, S.; Brownsort, P. 2011. Prospective life cycle carbon abatement for pyrolysis biochar systems in the UK, Energy Policy 39: 2646-2655.

https://doi.org/10.1016/j.enpol.2011.02.033

Jeffery, S.; Verheijen, F. G. A.; Velde, M.; Bastos, A. C. 2011. A quantitative review of the effects of biochar application to soils on crop productivity using meta-analysis, Agriculture, Ecosystems \& Environment 144: 175-187.

https://doi.org/10.1016/j.agee.2011.08.015

Jindo, K.; Sanchez-Monedero, M. A.; Hernandez, T.; Garcia, C.; Furukawa, T.; Matsumoto, K.; Sonoki T.; Bastida, F. 2012. Biochar influences the microbial community structure during manure composting with agricultural wastes, Science of the Total Environment 416: 476-481.

https://doi.org/10.1016/j.scitotenv.2011.12.009

Jonczyk, K.; Stalenga, J. 2010. Opportunities for development of different systems of agricultural production in Poland, Studia i Raporty IUNG-PIB, Puławy 22: 87-99 (in Polish).

Jośko, I.; Oleszczuk, P., Pranagal, J.; Lehmann, J.; Xing, B.; Cornelissen, G. 2013. Effect of biochars, activated carbon and multiwalled carbon nanotubes on phytotoxicity of sediment contaminated by inorganic and organic pollutants, Ecological Engineering 60: 50-59.

https://doi.org/10.1016/j.ecoleng.2013.07.064

Karczewska, A.; Kabała, C. 2010. The soils polluted with heavy metals and arsenic in Lower Silesia - the need and methods of reclamation, Zeszyty Naukowe Uniwersytetu Przyrodniczego we Wrocławiu, Rolnictwo XCVI, Nr 576.

Karhu, K.; Mattila, T.; Bergström, I.; Regina, K. 2011. Biochar addition to agricultural soil increased $\mathrm{CH} 4$ uptake and water holding capacity - results from a short-term pilot field study, Agriculture, Ecosystems and Environment 140: 309-313. https://doi.org/10.1016/j.agee.2010.12.005

Kloss, S.; Zehetner, F; Wimmer, B.; Buecker, J.; Rempt, F.; Soja, G. 2014. Biochar application to temperate soils: effects on soil fertility and crop growth under greenhouse conditions, Journal of Plant Nutrition and Soil Science 177: 3-15. https://doi.org/10.1002/jpln.201200282

Kloss, S.; Zehetner, F.; Dellantonio, A.; Hamid, R.; Ottner, F.; Liedtke, V.; Schwanninger, M.; Gerzabek, M. H.; Soja, G. 2012. Characterization of slow pyrolysis biochars: effects of feedstocks and pyrolysis temperature on biochar properties, Journal of Environmental Quality 41(4): 990-1000. https://doi.org/10.2134/jeq2011.0070

Khan, S.; Reid, B. J.; Li, G.; Zhu, Y. G. 2014. Application of biochar to soil reduces cancer risk via rice consumption: a case study in Miaoqian village, Longyan, China, Environment International 68: 154-161. https://doi.org/10.1016/j.envint.2014.03.017

Kishimoto, S.; Sugiura, G. 1985. Charcoal as a soil conditioner, International Achievements for the Future 5: 12-23.

Krasowicz, S.; Oleszek, W.; Horabik, J.; Dębicki, R.; Jankowiak, J.; Stuczyński, T.; Jadczyszyn, J. 2011. The rational management of environment of the soil in Poland, Polish Journal of Agronomy 7: 43-58 (in Polish).

Królczyk, J. B.; Latawiec, A. E.; Kuboń, M. 2014. Sustainable agriculture - the potential to increase yields of wheat and rapeseed in Poland, Polish Journal of Environmental Studies 23(3).

Kuka, K.; Franko, U.; Hanke, K.; Finkenbein, P. 2013. Investigation of different amendments for dump reclamation in Northern Vietnam, Journal of Geochemical Exploration 132: 41-53. https://doi.org/10.1016/j.gexplo.2013.05.001
Laird, D. A.; Fleming P.; Davis, D. D.; Horton, R.; Wang, B.; Karlen, D. L. 2010. Impact of biochar amendments on the quality of a typical Midwestern agricultural soil, Geoderma 158: 443-449. https://doi.org/10.1016/j.geoderma.2010.05.013

Lanza, G.; Rebensburg, P.; Kern J.; Lentzsch, P.; Wirth, S. 2016. Impact of chars and readily available carbon on soil microbial respiration and microbial community composition in a dynamic incubation experiment, Soil and Tillage Research 164: 18-24. https://doi.org/10.1016/j.still.2016.01.005

Latawiec, A. E.; Królczyk, J. B.; Kubon, M.; Szwedziak, K.; Drosik, A.; Polanczyk, E. Grotkiewicz K.; Strassburg, B. B. N. 2017. Willingness to adopt biochar in agriculture: The Producer's Perspective, Sustainability 9(4), 655. https://doi.org/10.3390/su9040655

Lehmann, J. 2007. Bio-energy in the black, Frontiers in Ecology and the Environment 5: 381-387. https://doi.org/10.1890/1540-9295(2007)5[381:BITB]2.0.CO;2

Lehmann, J.; Czimczik, C.; Laird, D.; Sohi, S. 2009. Stability of biochar in soil, Chapter 11, in J. Lehmann, S. Joseph (Eds.). Biochar for environmental management, science and technology. London: Earthscan.

Lehmann, J.; Joseph, S. 2009. Biochar systems, Chapter 9, in J. Lehmann, S. Joseph (Eds.). Biochar for environmental management, science and technology. London: Earthscan.

Lu, T.; Yuan, H.; Wang, Y.; Huang, H.; Chen, Y. 2016. Characteristic of heavy metals in biochar derived from sewage sludge, Journal of Material Cycles and Waste Management 18(4): 725-733. https://doi.org/10.1007/s10163-015-0366-y

Loska, K.; Wiechula, D.; Korus, I. 2004. Metal contamination of farming soils affected by industry, Environment International 30: 159-165. https://doi.org/10.1016/S0160-4120(03)00157-0

Łopatka, A.; Stuczyński, T.; Czyż, E., et al. 2007. Analysis of soil water conditions and risks of drought on the example of podlaskie province, Studia i Raporty IUNG-PIB 5: 79-105 (in Polish).

Malczewski, J. 2004. GIS-based land-suitability analysis: a critical overview, Progress in Planning 62(1): 3-65. https://doi.org/10.1016/j.progress.2003.09.002

Martin, I.; Morgan, H.; Waterfall, E. 2009. Science Report SC050021 / Cadmium SGV. SCHO0709BQRO-E-E. Environment Agency Soil Guideline Values for cadmium in soil.

Medyńska-Juraszek, A. 2014. Research report 2/2014. INoGiOŚ.

Michałek, R.; Kuboń, M. 2009. Postęp naukowo-techniczny i jego skutki społeczno-ekologiczne [Scientific and technological advances and their socio-ecological consequences], Inżynieria Rolnicza 1(110): 207-212 (in Polish).

Meyer, S.; Glaser, B; Quicker, P. 2011. Technical, economical, and climate-related aspects of biochar production technologies: a literature review, Environmental Science \& Technology 45: 9473-9483. https://doi.org/10.1021/es201792c

Major, J.; Rondon, M.; Molina, D.; Riha, S.; Lehmann, J. 2010. Maize yield and nutrition during 4 years after biochar application to a Colombian savanna Oxisol, Plant and Soil 333: 117-128. https://doi.org/10.1007/s11104-010-0327-0

Malińska, K.; Golańska, M.; Caceres, R.; Rorat, A.; Weisser, P.; Ślęzak, E. 2017. Biochar amendment for integrated composting and vermicomposting of sewage sludge - the effect of biochar on the activity of Eisenia fetida and the obtained vermicompost, Bioresource Technology 225: 206-214. https://doi.org/10.1016/j.biortech.2016.11.049 
Malińska, K.; Zabochnicka-Świątek, M.; Dach, J. 2014. Effects of biochar amendment on ammonia emission during composting of sewage sludge, Ecological Engineering 71: 474-478. https://doi.org/10.1016/j.ecoleng.2014.07.012

Malińska, K.; Zabochnicka-Świątek, M.; Cáceres, R.; Marfà, O. 2016. The effect of precomposted sewage sludge mixture amended with biochar on the growth and reproduction of Eisenia fetida during laboratory vermicomposting, Ecological Engineering 90: 35-41.

https://doi.org/10.1016/j.ecoleng.2016.01.042

Novak, J. M.; Busscher, W. J.; Laird D. L.; Ahmedna M.; Watts D. W.; Niandou M. A. S. 2009. Impact of biochar amendment on fertility of a southeastern coastal plain soil, Soil Science 174: 105-112.

https://doi.org/10.1097/SS.0b013e3181981d9a

Oleszczuk P.; Hale, S. E.; Lehmann, J.; Cornelissen, G. 2012a. Activated carbon and biochar amendments decrease porewater concentration of polycyclic aromatic hydrocarbons (PAHs) in sewage sludges, Bioresource Technology 111: 84-91. https://doi.org/10.1016/j.biortech.2012.02.030

Oleszczuk, P.; Rycaj, M.; Lehmann, J.; Cornelissen, G. 2012b. Influence of activatedcarbon and biochar on phytotoxicity of air-driedsewage sludges to Lepidium sativum, Ecotoxicology and Environmental Safety 80: 321-326.

https://doi.org/10.1016/j.ecoenv.2012.03.015

Oleszczuk, P.; Zielinska, A.; Cornelissen, G. 2014. Stabilization of sewage sludge by different biochars towards reducing freely dissolved polycyclic aromatic hydrocarbons (PAHs) content, Bioresource Technology 156: 139-145.

https://doi.org/10.1016/j.biortech.2014.01.003

Passuello, A.; Cadiach, O.; Perez, Y.; Schuhmacher, M. 2012. A spatial multicriteria decision making tool to define the best agricultural areas for sewage sludge amendment, Environmental International 38(1): 1-9.

https://doi.org/10.1016/j.envint.2011.07.013

Peake, L.; Freddo, A.; Reid, B. J. 2014. Sustaining soils and mitigating climate change using biochar, Chapter 7, in A. Des Las Heras, T. R. Macagno (Eds.). Sustainability science and technology, an introduction. Taylor\&Francis Group, CRC Press. https://doi.org/10.1201/b16701-8

Peng, X.; Ye, L. L.; Wang, C. H.; Zhou, H.; Sun, B. 2011. Temperature- and duration-dependent rice straw-derived biochar: characteristics and its effects on soil properties of an Ultisol in southern China, Soil \& Tillage Research 112: 159-166. https://doi.org/10.1016/j.still.2011.01.002

Powlson, D. S.; Whitmore, A. P.; Goulding, K. W. T. 2011. Soil carbon sequestration to mitigate climate change: a critical re-examination to identify the true and the false, European Journal of Soil Science 62(1): 42-55. https://doi.org/10.1111/j.1365-2389.2010.01342.x

Pylypiw, H. M.; Bugbee, G. J.; Frink, C. R. 1993. Uptake of preemergent herbicides by corn: distribution in plants and soil, Bulletin of Environmental Contamination and Toxicology 50(3): 474-478. https://doi.org/10.1007/BF00197210

Pylypiw, H. M.; Arsenault, T. L.; Thetford, C. M.; Mattina, M. J. I. 1997. Suitability of microwave-assisted extraction for multiresidue pesticide analysis of produce, Journal of Agricultural and Food Chemistry 45: 3522-3528. https://doi.org/10.1021/jf970227m

Rajkovich, S.; Enders, A.; Hanley, K.; Hyland, C.; Zimmerman, A. R.; Lehmann, J. 2012. Corn growth and nitrogen nutrition after additions of biochars with varying properties to a temperate soil, Biology and Fertility of Soils 48(3): 271284. https://doi.org/10.1007/s00374-011-0624-7

Reid, B. J.; Pickering, F. L.; Freddo, A.; Whelan, M. J.; Coulon, F. 2013. Influence of biochar on isoproturon partitioning and bioaccessibility in soil, Environmental Pollution 181: 44-50. https://doi.org/10.1016/j.envpol.2013.05.042

Roberts, K. G.; Gloy, B. A.; Joseph, S.; Scott, N. R.; Lehmann, J. 2010. Life cycle assessment of biochar systems: estimating the energetic, economic, and climate change potential, Environmental Science \& Technology 44.

https://doi.org/10.1021/es902266r

Schmidt, H.; Kammann, C.; Niggli C.; Evangelou, M. W. H.; Mackie, K. A.; Abiven, S. 2014. Biochar and biochar-compost as soil amendments to a vineyard soil: influences on plant growth, nutrient uptake, plant health and grape quality, Agriculture, Ecosystems \& Environment 191: 117-123. https://doi.org/10.1016/j.agee.2014.04.001

Shackley, S.; Ibarrola Esteinou, R.; Hopkins, D.; Hammond, J. 2014. Biochar Quality Mandate (BQM) version 1.0. British Biochar Foundation. 58 p.

Siebielec, G.; Smreczak, B.; Klimkowicz-Pawlas, A.; Maliszewska-Kordybach, B.; Terelak, H.; Koza, P.; Hryńczuk, B.; Łysiak, M.; Miturski, T.; Gałązka, R.; Suszek, B. 2012. Monitoring of the chemistry of arable soils in Poland in 2010-2012. IUNG-PIB (in Polish).

Siebielec, G.; Stuczyński, T.; Terelak, H.; Filipiak, K.; Koza, P.; Korzeniowska-Pucułek, R.; Łopatka, A.; Jadczyszyn, J. 2008. Determinants of agricultural production in regions with a high proportion of soils contaminated by trace metals, Studia $i$ Raporty IUNG-PIB 12: 123-143 (in Polish).

Singh, B.; Singh, B. P.; Cowie, A. L. 2010. Characterisation and evaluation of biochars for their application as a soil amendment, Soil Research 48(7): 516-525. https://doi.org/10.1071/SR10058

Smith, P. 2016. Soil carbon sequestration and biochar as negative emission technologies, Global Change Biology 22: 1315-1324. https://doi.org/10.1111/gcb.13178

SOER. 2010. European environment - state and outlook 2010. European Environment Agency.

Sohi, S. P. 2012. Carbon storage with benefits, Science 338(6110): 1034-1035. https://doi.org/10.1126/science.1225987

Sohi, S. P.; Krull, E.; Lopez-Capel, E. 2010. A review of biochar and its use and function in soil, Chapter 2, in D. L. Sparks (Ed.). Advances in agronomy, Vol. 105. Burlington: Academic Press. https://doi.org/10.1016/s0065-2113(10)05002-9

Sohi, S.; Loez-Capel, E.; Krull, E.; Bol, R. 2009. Biochar's roles in soil and climate change: a review of research needs. CSIRO Land and Water Science Report 05/09. 64 p.

Southavong, S.; Preston, T. R. 2011. Growth of rice in acid soils amended with biochar from gasifier or TLUD stove, derived from rice husks, with or without biodigester effluent. Livestock Research for Rural Development, 23.

Sparrevik, M.; Saloranta, T.; Cornelissen, G.; Eek, E.; Fet, A. M.; Breedveld, G. D.; Linkov, I. 2011. Use of Life cycle assessments to evaluate the environmental footprint of contaminated sediment remediation, Environmental Science \& Technology 45: 4235-4241. https://doi.org/10.1021/es103925u

Strassburg, B. B. N.; Latawiec, A. E.; Creed, A.; Nguyen, N.; Sunnenberg, G.; Miles, L.; Lovett, A.; Joppa, L.; Ashton, R.; 
Scharlemann, J. P. W.; Cronenberger, F.; Iribarrem, A. 2014. Biophysical suitability, economic pressure and land-cover change: a global probabilistic approach and insights for REDD+, Sustainability Science 9(2): 129-141. https://doi.org/10.1007/s11625-013-0209-5

Stuczyński, T.; Jadczyszyn, J. 2007. Digital map of Polish agricultural soil in scale 1:100000. IUNG-PIB (in Polish).

Sutrawska, M.; Kołodziejczyk, R. 2006. The use of plant protection products in Poland, Progres Plant Prot./Postępy Ochrony Roślin 46(1): 481-482 (in Polish).

Tammeorg, P. 2014. Softwood biochar as a soil amendment material for boreal agriculture: doctoral dissertation. University of Helsinki.

Terelak, H.; Stuczyński, T.; Piotrowska, M. 1997. Heavy metals in agricultural soils in Poland, Polish Journal of Soil Science 30 .

Tóth, G.; Hermann, T.; Szatmári, G.; Pásztor, L. 2016a. Maps of heavy metals in the soils of the European Union and proposed priority areas for detailed assessment, Science of the Total Environment 565: 1054-1062. https://doi.org/10.1016/j.scitotenv.2016.05.115

Tóth, G.; Hermann, T.; Da Silva, M. R.; Montanarella, L. 2016b. Heavy metals in agricultural soils of the European Union with implications for food safety, Environment International 88: 299-309. https://doi.org/10.1016/j.envint.2015.12.017

Turtoni, R.; Buera, S.; Boldrin, A.; Grosso, M.; Rigamonti, L.; Astrup, T. 2011. Life cycle assessment of waste incineration in Denmark and Italy using to LCA models, Waste Management Research 29: 78-90. https://doi.org/10.1177/0734242X11417489

Uchimiya, M.; Lima, I. M.; Klasson, T.; Wartelle, L. H. 2010. Contaminant immobilization and nutrient release by biochar soil amendment: roles of natural organic matter, Chemosphere 80 : 935-940. https://doi.org/10.1016/j.chemosphere.2010.05.020

Uzoma, K. C.; Inoue, M.; Andry, H.; Zahoor, A.; Nishihara, E. 2011. Influence of biochar application on sandy soil hydraulic properties and nutrient retention, Journal of Food, Agriculture and Environment 9: 1137-1134.

Vaccari, P. F.; Baronti, S.; Lugatoa, E.; Genesio, L.; Castaldi, S.; Fornasier, F. 2011. Biochar as a strategy to sequester carbon and increase yield in durum wheat, European Journal of Agronomy 34: 231-238.

https://doi.org/10.1016/j.eja.2011.01.006

Van Zwieten, L.; Kimber, S.; Downie, A.; Morris, S.; Petty, S.; Rust, J.; Chan, K. Y. 2010. A glasshouse study on the interaction of low mineral ash biochar with nitrogen in a sandy soil, Soil Research 48: 569-576. https://doi.org/10.1071/SR10003
Verheijen, F.; Jeffery, S.; Bastos, A. C.; Van der Velde, M.; Diafas, I. 2010. Biochar application to soils. A critical scientific review of effects on soil properties, processes, and functions. EUR, 24099, 162.

Weissteiner, C. J.; Pistocchi, A.; Marinov, D.; Bouraoui, F.; Sala, S. 2014. An indicator to map diffuse chemical river pollution considering buffer capacity of riparian vegetation - a panEuropean case study on pesticides, Science of The Total Environment 484: 64-73.

https://doi.org/10.1016/j.scitotenv.2014.02.124

Werner, D.; Higgins, C. P.; Luthy, R. G. 2005. The sequestration of PCBs in Lake Hartwell sediment with activated carbon, Water Research 39(10): 2105-2113. https://doi.org/10.1016/j.watres.2005.03.019

Yamato, M.; Okimori, Y.; Wibowo, I. F.; Anshori, S.; Ogawa, M. 2006. Effects of the application of charred bark of Acacia mangium on the yield of maize, cowpea and peanut, and soil chemical properties in South Sumatra, Indonesia, Soil Science and Plant Nutrition 52: 489-495. https://doi.org/10.1111/j.1747-0765.2006.00065.x

Yang, Z. B.; Rao, I. M.; Horst, W. J. 2013. Interaction of aluminium and drought stress on root growth and crop yield on acid soils, Plant and Soil 372(1-2): 3-25. https://doi.org/10.1007/s11104-012-1580-1

Yeboah, E.; Ofori, P.; Quansah, G.; Dugan, E.; Sohi, S. 2009. Improving soil productivity through biochar amendments to soils, African Journal of Environmental Science and Technology 3: 34-41.

Zhang, Y.; Chen, T.; Liao, Y.; Reid, B. J.; Chi, H.; Hou, Y.; Cai, C. 2016. Modest amendment of sewage sludge biochar to reduce the accumulation of cadmium into rice (Oryza sativa L.): a field study, Environmental Pollution 216: 819-825. https://doi.org/10.1016/j.envpol.2016.06.053

Zheng, R.; Chen, Z.; Cai, C.; Tie, B.; Liu, X.; Reid, B. J.; Huang, Q.; Lei, M., Sun, G.; Baltrènaite, E. 2015. Mitigating heavy metal accumulation into rice (Oryza sativa L.) using biochar amendment - a field experiment in Hunan, China, Environmental Science and Pollution Research 22(14): 1109711108. https://doi.org/10.1007/s11356-015-4268-2

Zimmerman, A. R.; Gao, B.; Ahn, M. 2011. Positive and negative carbon mineralization priming effects among a variety of biochar-amended soils, Soil Biology and Biochemistry 43(6): 1169-1179. https://doi.org/10.1016/j.soilbio.2011.02.005

Zimmerman, J. R.; Ghosh, U.; Millward, R. N.; Bridges, T. S.; Luthy, R. G. 2004. Addition of carbon sorbents to reduce PCB and PAH bioavailability in marine sediments: physicochemical tests, Environmental Science \& Technology 38(20): 5458-5464. https://doi.org/10.1021/es034992v

Agnieszka E LATAWIEC is Executive Director of the International Institute for Sustainability in Rio de Janeiro (IIS-Rio) and coordinator of the Rio Conservation and Sustainability Science Centre (CSRio) at the at the Department of Geography and Environment at the Pontifical Catholic University of Rio de Janeiro (PUC-Rio) - Brazil (where she is Associate Professor). She is also Associate Professor at the Faculty of Production and Power Engineering at the University of Agriculture in Krakow, Poland and Honorary Lecturer of the University of East Anglia. She is interested in interdisciplinary research linking soil science with social science.

Lewis PEAKE. Dr, Soil Scientist, specialising in Agricultural Land Classification (ALC); Visiting Fellow and Associate Tutor in the School of Environmental Sciences and in the School of International Development, University of East Anglia (UEA), Norwich; Full member of the British Society of Soil Science (BSSS); Research interests: biochar, sustainable agriculture, ecosystem services of soils. 
Helen BAXTER. Dr H. Baxter works at the University of Glasgow, as part of the National Centre for Resilience (NCR), School of Interdisciplinary Studies where her role is to develop and conduct research to improve Scottish communities' resilience to natural hazards. Before taking on this role she worked at University of Hull as a PDRA on the R3AW (Resource Recovery and Remediation of Alkaline Wastes) project, bringing together the physical science and engineering with the social science, quantifying the impacts of the remediation system being developed using LCSA methodologies. Her $\mathrm{PhD}$, from the University of Hull, was concerned with environmental remediation integrating LCA an ecosystem services approach; "The development of a novel framework to assess the viability; environmentally, economically and socially of differing remediation technologies for the remediation of wastewater from abandoned metal mines: Applied to a case study of an abandoned noncoal mines site in the Yorkshire Dales National Park". Pryor to that she completed an MSc in Environmental Technology part of which was a research project comparing the alternative uses of biochar in Senegal. She was an undergraduate at the University of Southampton where she gained a BSc (Hons) in "Oceanography with Geology".

Gerard CORNELISSEN is a technical expert at the Norwegian Geotechnical Institute and a professor at the Norwegian University of Life Sciences. He is leading multidisciplinary biochar projects in Zambia, Nepal and Indonesia.

Katarzyna GROTKIEWICZ, PhD, Eng., works in the Department of Production and Power Engineering which is the Institute of Agricultural Engineering and Informatics of the University of Agriculture in Krakow, Poland. Her areas of scientific interest include: economic situation of the agricultural sector in the EU Member States and in the world, analysis of agricultural and economic indicators, sustainable development of agriculture, competitiveness and innovation of the agricultural sector, modelling using statistic models to predict the development of economical and agricultural indicators.

Sarah HALE completed her PhD at Newcastle University, UK focused on the remediation of contaminated land using sorbent amendment. Her current work at the Norwegian Geotechnical Institute focuses on the use of biochar to improve the quality of degraded agricultural soils.

Jolanta B KRÓLCZYK is an Associate Professor in the Department of Manufacturing Engineering and Production Automation in Opole University of Technology. She is also associated with the industry, where she has held positions such as: Environmental Consultant, Project Manager, Product Engineer and Managing Director of a manufacturing company. The area of her scientific research concerns agricultural engineering, production engineering and the construction and exploitation of machines. Within the framework of scientific cooperation Jolanta Beata Królczyk was a participant of internships in institutions such as: Fachhochschule Trier, University of Applied Science (Germany), International Institute for Sustainability w Rio de Janeiro (Brazil), Utah State University (USA). In 2013 she participated in Top 500 Innovators Program in Haas School of Business in University of California, Berkeley (USA). Author and co-author over 100 scientific publications and implementation activities to the industry. Scientific membership in: TEAM Society - Technique, Education, Agriculture \& Management and TOP500 Association.

Maciej KUBON. He is Prof. employed at the University of Agriculture in Krakow. His scientific interests focus on the sustainable development of rural areas, transport and logistics in agricultural engineering and efficiency of logistic infrastructure use. He has written 137 scientific papers including 11 monographies. He is a secretary of scientific journal "Agricultural Engineering", member of KIR, PTIR, STIR and POLISTA.

Artur ŁOPATKA is a research scientist at the Department of Soil Science, Erosion and Land Protection of at the Institute of Soil Science and Plant Cultivation - State Research Institute (IUNG) in Pulawy, Poland. His areas of interest and research are applications of econometric, GIS, statistics, System Dynamic Modelling, agent based modelling, optimization and control theory methods in agriculture; valorisation of agricultural production area; application of satellite imaginary for estimation of soil degradation, soil moisture and plant water stress; soil moisture and crop yield interactions modelling; agricultural policy impact assessment.

Agnieszka MEDYNSKA-JURASZEK is an assistant professor in Institute of Soil Sciences and Environmental Protection, Wroclaw University of Environmental and Life Sciences. Her research interest include heavy metal pollution in soil, use of organic matter in soil remediation, soil organic matter interaction with organic and inorganic pollutants. Nowdays mainly focusing on biochar application as a soil amendment and its use in agriculture, horticulture and soil remediation. Her research has been published in Environmental Monitoring and Assessment, Journal of Plant Nutrition and Soil Science and Environmental Sciences Pollution Research.

Brian J REID is a Reader in Soil Science at the University of East Anglia and holds an Adjunct Professorship with the Chinese Academy of Science. He is a Technical Expert in Soil Quality to the BSI and a member of the ISO Soil Quality Technical Committee - TC190. His research focuses on soil ecosystem services and in particular interactions between: soil, biochar, contaminants, agrochemicals and nutrients. 
Grzegorz SIEBIELEC is a research scientist at the Institute of Soil Science and Plant Cultivation - State Research Institute (IUNG) in Pulawy, Poland. He received a PhD in agronomy in 2001. Current head of Soil Science Erosion and Land Protection at IUNG. His main research interests are soil contamination and remediation, land use change, soil quality, soil sealing, waste management. He has participated in 12 international projects, including 5, 6 and 7FP. Coordinated program of national monitoring of soil quality. Currently a national representative for soil issues in EIONET, Common Forum on Contaminated Lands and Global Soil Partnership.

Saran P SOHI. Saran holds an academic position at the University of Edinburgh, School of GeoSciences. His research is focused on the interface of land use and environment, specifically the management of the plant-soil interface in agriculture and forestry. He is interested in the flexibility offered by the pyrolysis / biochar proposition over time and space, drawing on laboratory-based understanding within the UK Biochar Research Centre (UKBRC).

Zofia SPIAK. She is Prof. Dr hab., Chair of Dept. of Plant Nutrition, UPW. Major research interest and publication activity: plant fertilization in relation to organic matter transformation, and different ways of macro- and micro- fertilization. The author and co-author of 203 full-version papers (12 published in JCR indexed journals, 7 book chapters, $\sim 119$ poster \& oral presentation at international and national conferences. Citations (without self-citations) (Web of Sci. All Databases) $=$ 18; $\mathrm{h}$ index $=3$. Leader in 8 national projects, Principal investigator in 7 national projects \& 1 international. Co-author of 1patent P 215119. Research experience: visiting professor China, Greece, Denmark, Germany. Awards: 2011 1st price of National Technical Organization for innovative technology "Methods of revitalization of landfills minerals, especially soilless land". Golden Medal of Brussel Fair Eureka.

Bernardo BN STRASSBURG is Executive Director of the International Institute for Sustainability in Rio de Janeiro and Assistant Professor at the Pontific Catholic University of Rio de Janeiro where he also coordinates Rio Conservation and Sustainability Science Centre. Bernardo is an economist with a MSc in environmental planning (focused on land-use change and ecosystem services in the Amazon), and $\mathrm{PhD}$ in Environmental Sciences, focused on issues related to reducing emissions from deforestation and forest degradation (REDD+). He is dedicated to the transition to sustainability with focus on the sustainable use of land and its resources conciliating production needs, environmental services and social development by developing interdisciplinary research, providing assistance to governments, NGO's and private companies in the pursue of solutions to sustainability challenges and implementation of projects. 